\title{
Abnormal returns, risk, and financial statement data: The case of the Iraqi invasion of Kuwait
}

\author{
Bruce M. Bradford \\ Fairfield University, bbradford@fairfield.edu \\ H. David Robison
}

Follow this and additional works at: https://digitalcommons.fairfield.edu/business-facultypubs Copyright 1997 Elsevier

"NOTICE: this is the author's version of a work that was accepted for publication in Journal of Economics and Business. Changes resulting from the publishing process, such as peer review, editing, corrections, structural formatting, and other quality control mechanisms may not be reflected in this document. Changes may have been made to this work since it was submitted for publication. A definitive version was subsequently published in Journal of Economics and Business 49, no. 2 (1997): 193-204. DOI\# 10.1016/S0148-6195(97)81515-9

\section{Peer Reviewed}

\section{Repository Citation}

Bradford, Bruce M. and Robison, H. David, "Abnormal returns, risk, and financial statement data: The case of the Iraqi invasion of Kuwait" (1997). Business Faculty Publications. 152.

https://digitalcommons.fairfield.edu/business-facultypubs/152

\section{Published Citation}

Bradford, Bruce M., and H. David Robison. "Abnormal returns, risk, and financial statement data: The case of the Iraqi invasion of Kuwait." Journal of Economics and Business 49, no. 2 (1997): 193-204.

This item has been accepted for inclusion in DigitalCommons@Fairfield by an authorized administrator of DigitalCommons@Fairfield. It is brought to you by DigitalCommons@Fairfield with permission from the rightsholder(s) and is protected by copyright and/or related rights. You are free to use this item in any way that is permitted by the copyright and related rights legislation that applies to your use. For other uses, you need to obtain permission from the rights-holder(s) directly, unless additional rights are indicated by a Creative Commons license in the record and/or on the work itself. For more information, please contact digitalcommons@fairfield.edu. 


\title{
ABNORMAL RETURNS, RISK, AND FINANCIAL STATEMENT DATA: THE CASE OF THE IRAQI INVASION OF KUWAIT
}

\author{
Bruce M. Bradford* \\ and
}

H. David Robison**

Running Title: Invasion of Kuwait

August 1996

Please do not quote.

*Assistant Professor of Accounting, School of Business, Fairfield University, Fairfield, CT 06430-5195, (203) 254-4000 ex. 2825. (Corresponding author)

* Associate Professor, Department of Economics, La Salle University, 1900 West Olney Avenue, Philadelphia, PA 19141, (215) $951-1184$. 


\title{
ABNORMAL RETURNS, RISK, AND FINANCIAL STATEMENT DATA: THE CASE OF THE IRAQI INVASION OF KUWAIT
}

\begin{abstract}
This paper examines abnormal returns and changes in risk for transportation firms immediately around the Iraqi invasion of Kuwait. Further, it tests whether the variation in the abnormal returns can be explained cross-sectionally with standard financial and industry-descriptive variables. The results indicate that transportation firms suffered a -2.09 percent abnormal return and increases in unsystematic risk. The crosssectional regression explains 31 percent of the variation in the abnormal returns, with firm size, liquidity, leverage, percentage of sales to the Defense Department, and dummy variables denoting firms producing recreational vehicles or owning oil-producing subsidiaries contributing significantly to the regression.
\end{abstract}

Keywords: Event study, macroeconomic shock, and cross-sectional analysis. 


\section{ABNORMAL RETURNS, RISK, AND FINANCIAL STATEMENT DATA: THE CASE OF THE IRAQI INVASION OF KUWAIT}

\section{INTRODUCTION}

On August 2, 1990 Iraqi troops poured over the Kuwaiti border and extended Saddam Hussein's control to eight percent of the world oil supply. The invasion raised questions about the direction of the U.S. economy and financial markets. Extensive media coverage, including over 200 articles in the first six days following the invasion in the Wall street Journal and New York Times, fueled speculation which ran the gamut from quiet withdrawal to a broad regional conflict (see Table 1). Professional forecasters and analysts tended to focus on the impact of the increase in oil prices from $\$ 19$ to $\$ 41$ per barrel within two months of the invasion. For example Ratajezak (1990) anticipated that the resulting inflation would add to the recessionary pressures which were building prior to the invasion. In addition, the uncertainty surrounding the security of Persian Gulf oil would result in a substantial risk premium for the spot price of oil.

The purpose of this research is to extend the literature on the effects of oil shocks on security valuation. Specifically, this paper examines abnormal returns, variation in abnormal returns, and changes in risk for firms in the transportation industry immediately around the Iraqi invasion of Kuwait. Of particular interest is the question of whether the variation in 
abnormal returns can be explained cross-sectionally using financial statement and other data available ex-ante to investors. Finding that the financial and descriptive data explain a significant proportion of the abnormal returns suggest that this data provide a contextual framework for evaluating the impact of an oil-shock. This paper is motivated by the opportunity to extend the analysis of standard microeconomic shocks (e.g., chemical, airline, and nuclear accidents) ${ }^{1}$ to a multi-dimensional macroeconomic shock. Investors might reasonably use the Arab oil embargo as a basis for building expectations. Sach (1982) indicated that the Arab oil embargo triggered an inflationary recession similar to that anticipated by Ratajezak (1990). In addition, the financial markets during the embargo were characterized by increased common stock price volatility [Kaul and Seyhun (1990)]. However, unlike the Arab oil embargo, the invasion created an immediate threat of war which meant potential gains for firms providing military goods or services. Another difference between the reaction to the invasion and the Arab oil embargo was Saddam Hussein's well-known connections to terrorist groups which threatened airline travel. Thus, while the Arab oil embargo provides a basis for investors to form expectations about the impacts of oil price changes, the two events are unique.

The transportation industry, including production of transportation equipment and transportation services, was chosen for this study because they should be disproportionately affected by the oil shock [Bauer and Byrne (1991)]. Meckstroth and Buckley 
(1991) indicate that transportation, both consumer and commercial, consumed 64 percent of the 1989 U.S. oil supply. In comparison, the manufacturing, residential, and utility sectors consumed 16, 5, and 3 percent, respectively. Firms providing transportation services will feel both the increase in the cost of providing the services due to high input costs and the drop in demand associated with the recession. On the other hand, transportation manufacturers will feel relatively little cost effect, but strong demand-side effects as both the fall in income and the rise in oil prices will affect purchasers decisions about whether to purchase new equipment and which equipment to purchase. For example, with rising oil prices and falling incomes, consumers are likely to shift to smaller, more fuel efficient, cars. Both the decrease in demand and the increase in operating costs could lead to significant cash-flow problems for many transportation firms.

\section{ABNORMAL RETURNS AND RISK}

\section{Data}

The initial sample was derived by searching the Center for Research in security Prices (CRSP) data file for firms which produce transportation equipment or provide transportation services. The 2-digit standard Industrial Classification (SIC) codes of $37,40,41,42,44$, and 45 were included in the sample. To be included in the final sample, firms also had to meet the following three criteria:

(1) Firms had to have no significant announcement in the 15 
days prior to or 15 days following the invasion of Kuwait. Among the confounding events which would cause removal of the firm included changes in dividends, issuance or reacquisition of securities, and mergers or divestitures.

(2) Firms must have traded a sufficient number of trading days to permit estimation of the market model and had no days missing in the event window.

(3) Third, each firm had to have complete financial statement data available for inclusion in the cross-sectional regression.

A total of 81 firms met all of these requirements and are used in the tests presented below.

\section{Abnormal Returns Method}

Following Blacconiere and Patten (1994), coefficients are estimated for the portfolio of 81 transportation firms by using the standard market model (1). Then cumulative abnormal returns (CAR) are calculated over various intervals within the 31 day event window using equation (2). ${ }^{2}$ Bernard (1987) recommended the use of this portfolio approach to avoid any potential bias from crosssectional dependence associated with event clustering. Furthermore, to avoid potential problems from changes in beta, the market model coefficients are estimated for each firm using a postestimation period, i.e., data from after the war. ${ }^{3}$

$$
R_{p t}=\alpha_{p}+\beta_{p} R_{m t}+e_{p t}
$$




$$
C A R_{p}=\sum_{t=a}^{b}\left[R_{p t}-\left(\hat{\alpha}_{p}+\hat{\beta}_{p} R_{m t}\right)\right]
$$

where,

$$
\begin{aligned}
\mathrm{R}_{\mathrm{pt}}= & \text { equally weighted returns for portfolio } \mathrm{p} \text { of } \\
& \text { transportation firms on day } \mathrm{t} . \\
\mathrm{R}_{\mathrm{mt}}= & \text { CRSP value-weighted market return for day } t . \\
\alpha_{\mathrm{p}}= & \text { intercept coefficient for portfolio } \mathrm{p} . \\
\beta_{\mathrm{p}}= & \text { slope coefficient for portfolio } \mathrm{p} . \\
e_{\mathrm{pt}}= & \text { error term for portfolio } \mathrm{p} \text { on day } t . \\
\mathrm{CAR}_{\mathrm{p}}= & \text { cumulative abnormal returns for portfolio } \mathrm{p} \\
& \text { over an interval from day a to } \mathrm{b} .
\end{aligned}
$$

Blacconiere and Patten (1994) present a nonparametric test for the significance of CAR. After determining CAR for a specific interval, e.g., days 0 to 5 with day 0 being the event date, 999 randomly generated 'pseudo' event dates were generated for the period from one year before to one year after the invasion. The 'pseudo' CARs for the equivalent six day intervals were calculated. The level of significance of the original CAR for that specific interval is then calculated directly (3).

$$
\mathrm{p}=(\mathrm{NLE}+1) /(\mathrm{NS}+1)
$$

where,

$$
\begin{aligned}
\mathrm{NLE}= & \text { number of times the 'pseudo' CAR is less than or } \\
& \text { equal to CAR. } \\
\mathrm{NS}= & \text { number of 'pseudo' CARs generated }
\end{aligned}
$$

This test is not based on the assumption of normality, and it is 
robust against the effects of cross-sectional dependence from event clustering.

\section{Risk Method}

Changes in risk associated with transportation firms in response to the invasion of Kuwait are examined. With uncertainty about changes in unsystematic risk, a seemingly unrelated regressions technique [Zellner (1962)] is used to simultaneously test for both changes in systematic risk (beta) and unsystematic risk (variance of the error terms). ${ }^{4}$ The period of study is divided into three periods for these comparisons. Periods A, B, and $\mathrm{C}$ are the period before the invasion (days -215 to -16), the period including the invasion and Persian Gulf war (days -15 to 160), and the period beginning 15 days after the end of the war (days 161 to 360), respectively. In the analysis of risk, period $A$ is compared to period $C$ to determine if there were significant increases in beta or error variances. ${ }^{5}$ Specifically, the following pair of equations are estimated for each firm:

$$
\begin{aligned}
& R_{j, t, A}=\alpha_{j, A}+\beta_{j, A} R_{m t, A}+e_{j, t, A} \\
& R_{j, t, c}=\alpha_{j, c}+\beta_{j, c} R_{m t, c}+e_{j, t, c}
\end{aligned}
$$

where

$$
\begin{aligned}
R_{j, t, p}= & \text { return on security } j \text { for day } t \text { of period } p ; \\
\alpha_{j, p}= & \text { intercept for the security } j \text { in period } p ; \\
\beta_{j, p}= & \text { slope (systematic risk) for the security } j \text { in } \\
& \text { period } p ;
\end{aligned}
$$




$$
\begin{aligned}
R_{m t, p}= & \text { equally weighted CRSP index for the security } j \text { in } \\
& \text { period } p ; \\
e_{j, t, p}= & \text { error term for security } j \text { on day } t \text { in period } p .
\end{aligned}
$$

To test for changes in systematic risk, the null hypothesis, $\beta_{j, c}-\beta_{j, A}=0$, is examined. To test for changes in unsystematic risk, the ratio of error variances for each period (Var $e_{t, c} /$ Var $\left.e_{t, A}\right)$ is examined ${ }^{6}$ [see Chandy and Karafiath (1989); Bowen, et al. (1983)].

\section{Results and Discussion}

As summarized in Table 2, the portfolio CARs are negative for most of the post-invasion intervals tested. Most of the market reaction occurs in the six-day period immediately following the invasion (days 0 to 5) where the cumulative abnormal returns are -2.09 percent $(\alpha=0.015)$. These findings are consistent with the abnormal losses of electric utility firms during the Arab oil embargo [Norton (1988)]. Investors should expect oil-dependent industries such as transportation or utilities to respond with abnormal losses to the invasion of Kuwait.

The Wilcoxon Signed-Ranks Test is used to examine changes in systematic and unsystematic risk for individual firms and the portfolio of transportation firms. The results are summarized in Table 3. As can be seen in Panel A, no significant change in systematic risk is found for individual firms. Only about half the sample, 41 of the 81 firms, demonstrate positive shifts in systematic risk. In contrast, unsystematic risk is found to be 
significantly greater after the Persian Gulf war than before the invasion $(\alpha=0.01)$, with over three-quarters, 64 of the 81 firms, showing increased risk. Panel B examines changes in risk for the firms treated as a single portfolio. Again, the change in systematic risk is insignificant, while the increase in unsystematic risk is significant $(\alpha=0.10)$. These results are consistent with Uselton and Fraser (1988) in that the change in risk associated with the invasion of Kuwait affected unsystematic risk not systematic risk. However, the oil-dependent transportation firms demonstrated increased unsystematic risk rather than a decrease as demonstrated by petroleum firms in response to the Arab oil embargo. Both these results and Uselton and Fraser (1988) are consistent with those of Chen, et al. (1986), who found that the risk of oil price changes was not priced by the overall market at the time of the Arab oil embargo.

\section{CROSS-SECTIONAL REGRESSION}

\section{Data, Method, and Expectations}

Investors attempting to assess the impact of the invasion on individual firms would consider each firm's market position, cost structure, and financial condition in light of the specific industry segments in which it operates. We attempt to capture these considerations by including both financial and descriptive variables in a cross-sectional regression. The financial variables were selected as proxies for financial flexibility, which the Financial Accounting Standards Board (1984) describes as, "the 
ability of an entity to take effective actions to alter amounts and timing of cash flows so it can respond to unexpected needs and opportunities." The descriptive variables were selected to identify firms which would have unusual or disproportionate impacts on the whole as a result of the industry segments in which they operate. ${ }^{7}$

Our approach to selecting financial variables comes from Ohlson's (1980) classic bankruptcy study. In his study, Ohlson finds four constructs of a firm's financial condition (i.e., size, leverage, performance, and liquidity) which contribute to the explanation of bankruptcy. To the extent that these constructs capture financial flexibility, they may contribute to the prediction of abnormal returns associated with an oil shock. For example, firm size suggests the ability to generate cash through the sale of assets or other management actions. Other things equal, larger firms should have greater financial flexibility than smaller firms. Similarly, the high fixed costs associated with debt will cause highly leveraged firms to suffer more severely from a recession-induced drop in demand than firms with lower levels of debt. Low debt firms might also have the flexibility to borrow to increase market share by acquiring financially troubled competitors. Along the same lines, performance is suggestive of several factors including operational efficiency and managerial talent, while liquidity relates to a firm's ability to meet shortterm financial obligations or respond to opportunities. Together, this information gives some insight into the ability of firms to 
cope with the financial strain arising from the circumstances surrounding the invasion, in essence, their financial flexibility. Our proxies for size, leverage, performance, and liquidity are the natural log of total assets (LNTA), the ratio of total liabilities to total assets (TLTA), the ratio of net income to total assets (NITA), and the current ratio (CACL), respectively. ${ }^{8}$ We expect a negative coefficient for leverage and positive coefficients for the measures of size, performance, and liquidity. Finding significant coefficients on these variables will suggest that financial statement data contribute to the explanation of how investors react to a macroeconomic shock in a period of uncertainty

The first two of four descriptive variables included in the regression are mitigating factors which reduce the abnormal losses expected for specific firms compared to the average transportation firm. Some transportation firms are involved in the manufacture of defense related items. It seems reasonable to expect sales of defense related products to increase during the unsettled period surrounding the invasion of Kuwait and subsequent Persian Gulf War. A few transportation firms have petroleum producing subsidiaries. Given the positive abnormal returns of petroleum companies associated with the invasion of Kuwait [Bradford and Robison (1992)], the sale of petroleum products should also mitigate the effects of the invasion for those firms. Defense sales are captured as a percentage of each firm's sales made to the U.S. department of defense ${ }^{9}$ (PCDEF) and the production of petroleum 
(PROD) is captured as a dummy variable with the value of one for petroleum production and zero otherwise. Both variables are expected to have positive coefficients.

The third and fourth descriptive variables identify firms which are likely to be hit harder by the oil shock than the average transportation firm. According to Thomchick (1993), airlines are heavily impacted by the invasion of Kuwait because of their energy demands, reduction in demand, and increases in non-energy operating costs such as insurance and security. The most significant impact to the airline industry probably would be due to the impact of oil since 20 percent of their operating costs is fuel and they depend on the spot market for their supply of oil [Bauer and Byrne (1991)]. Manufacturers of recreational vehicles also would be heavily impacted by the invasion. Recreational vehicles have extremely high income elasticities as well as high oil price elasticities which suggests a rapid drop in demand would likely result from the oil shock. Unlike auto manufacturers, they produce a limited product line which provides little opportunity to mitigate the effects of the oil shock by changing their product mix. Dummy variables are used to identify firms as airlines (AIR) or manufacturers of recreational vehicles (RV) with a value of one and zero otherwise. Both variables are expected to have negative coefficients.

The dependent variable for the cross-sectional regression is the six day cumulative abnormal returns (days 0 to 5). This period captures most of. the market reaction to the invasion and the 
initiation of Desert Shield. This relatively small interval, ending with the sending of U.S. troops to Saudi Arabia, is selected in order to assure capturing the period of greatest uncertainty about the outcome which ends with a clear commitment on the part of the U.S. and its allies to halt Saddam Hussein's aggression. ${ }^{10}$ Thus, the full model, estimated using ordinary least squares, is:

$$
\begin{aligned}
\mathrm{CAR}_{j} & =\beta_{0}+\beta_{1} \mathrm{LNTA}_{j}+\beta_{2} \mathrm{NITA}_{j}+\beta_{3} \mathrm{CACL}_{j}+\beta_{4} \mathrm{TLTA}_{j} \\
& +\beta_{5} \mathrm{PCDEF}_{j}+\beta_{6} \mathrm{PROD}_{j}+\beta_{7} \mathrm{AIR}_{j}+\beta_{8} \mathrm{RV}_{j}+e_{j}
\end{aligned}
$$

where,

$$
\begin{aligned}
\operatorname{CAR}_{j}= & \text { the cumulative abnormal returns for firm } j \text { over the } \\
& \text { interval from day } 0 \text { through day } 5 ; \\
\beta_{i}= & \text { the parameter estimates; } \\
e_{j}= & \text { the error term for firm } j ; \text { and all other variables } \\
& \text { are as defined above. }
\end{aligned}
$$

\section{Results and Discussion}

The results of the cross-sectional regression are presented in Table 4. The model, as a whole, explains more than 31 percent of the variation in the six-day cumulative abnormal returns and is statistically significant $(F=4.08, \alpha=0.01)$. The size, leverage, and liquidity variables all have the expected signs and are statistically significant. These results suggest that investors are using the available financial and descriptive information to revise expectations about the value of firms and provide evidence that firms with greater financial flexibility fare better in times 
of macroeconomic shocks. On the other hand, the performance variable is not significant which suggests that past performance does not indicate the ability of a firm to rapidly respond to external shocks.

Among the descriptive variables in the model, the percentage of sales to the U.S. Department of Defense and the identification of petroleum producers, have significantly positive coefficients confirming the potential for increased sales of defense or petroleum products mitigates losses. The dummy variable for producers of recreational vehicles (RV) has a significant negative coefficient, indicating that these firms suffer more from recessionary or inflationary expectations than other transportation firms. Finally, the airline variable (AIR) has the expected negative sign, but is not significant at conventional levels. This result is somewhat surprising and may reflect that the market does not anticipate losses to the airlines which are markedly different from other transportation firms.

\section{SUMMARY AND CONCLUSION}

The invasion of Kuwait led to significant abnormal losses over the period from day 0 through day 5 and an increase in unsystematic risk for transportation firms. A cross-sectional regression explains 31 percent of the variation in the cumulative six-day abnormal return, with the size, leverage, and liquidity variables contributing significantly. of the descriptive variables, manufacturers of large recreational vehicles suffered greater than 
average losses, while firms with oil producing subsidiaries or with substantial defense industry sales suffered smaller than average abnormal losses. These results are interpreted as being consistent with the idea that investors use financial statement and industry-specific information as a context for evaluating the effects of macroeconomic shocks.

This research has several practical implications for investors. First, it reaffirms the importance of the financial statement data and descriptive information regarding the segment in which firms operate. Second, the potential for external shocks should be considered in stock selection. Consistent with the literature, the results suggest that the abnormal returns are conditioned on firms' exposure to economic events [Chalk (1987); Mitchell and Maloney (1989); Bowen, et al. (1983); Kalra, et al. (1993); Blacconiere and Patten (1994)]. Finally, the finding that firms with greater financial flexibility have smaller abnormal losses at the time of the shock, suggests that financial flexibility should be a consideration in stock selection. 


\section{NOTES}

1. Examples of microeconomic shocks resulting in significant abnormal losses are Three Mile Island [Bowen, et al. (1983)], Chernobyl [Kalra, et al. (1993)], Bhopal [Blacconiere and Patten (1994)], and various airline crashes [Michell and Maloney (1989); Chalk (1986; 1987); Borenstein and Zimmerman (1988)].

2. As an alternative to this nonparametric approach, a standard event study method [Dodd and Warner (1983)] was also conducted yielding similar findings. The method presented is preferred because of its robustness with regard to event clustering.

3. The post-estimation period was the 200 day period beginning 15 days after the end of the Persian Gulf war (days 161 to 360 ).

4. Some microeconomic shocks have been associated with changes in systematic risk, unsystematic risk, or both, e.g., Bowen et al. (1983), Kalra et al. (1993), and Chandy and Karafiath (1989).

5. Period B was ignored because of a myriad of additional announcements (e.g., the start of the ground war) that might affect parameter estimates.

6. The ratio of error variances (Var $e_{t C} /$ Var $e_{t_{A}}$ ) follows an F-distribution with 200 degrees of freedom for both numerator and denominator.

7. The descriptive variables are used to capture the firm's exposure to the effects of the event. For instance, Bowen et al. (1983) find that firms with large commitments to nuclear power suffer losses significantly larger than non-nuclear firms after 
Three Mile Island. Similarly, Kalra et al. (1993) find that firms with large commitments to new nuclear capacity suffered significant negative abnormal returns after Chernobyl, while non-nuclear and firms with fully operating nuclear plants suffered small and transitory losses.

8. These ratios were also examined after standardization by their industry norms as suggested by Lev and Sunder (1979). No improvement in explanatory power was observed so the simpler form is presented.

9. Based on 500 contractors: Contractors receiving the largest dollar volume of prime contract awards for RDT\&E. 10. Several modifications of this six-day interval, including the thirty-one day event window, were examined. The results were not materially different from those presented. 


\section{REFERENCES}

Bauer, P. W., and Byrne, S. M. (January 15, 1991.) The sectoral and regional effects of oil shocks: Who's over a barrel? Economic Commentary [Federal Reserve Bank of Cleveland] : $1-4$

Bernard, V. L. (Spring 1987.) Cross-sectional dependence and problems in interference in market-based research. Journal of Accounting Research 25: 1-48.

Blacconiere, W. G., and Patten, D. M. (1994.) Environmental disclosure, regulatory costs, and changes in firm value. Journal of Accounting and Economics 18: 357-377.

Borenstein, S., and Zimmerman, M. B. (1988.) Market incentives for safe commercial airline operation. American Economic Review 78: 913-935.

Bradford, B. M., and Robison, H. D. (1992.) The Iraqi invasion of Kuwait and petroleum stock returns. Southern Business and Economic Journal 15: 223-233.

Bowen, R. M., Castanias, R. P., and Daley, L. A. (1983.) Intraindustry effects of the accident at Three Mile Island. Journal of Financial and Quantitative Analysis 18: 87-111.

Chalk, A. (1986.) Market forces and aircraft safety: The case of the DC-10. Economic Inquiry 25: 43-60.

Chalk, A. J. (1987.) Market forces and commercial aircraft safety. Journal of Industrial Economics 36: 61-81. 
Chandy, P. R., and Karafiath, I. (1989.) The effect of the wPPSS crisis on utility common stock returns. Journal of Business Finance and Accounting 16: 531-542.

Chen, N. F., Roll, R., and Ross, S. A. (1986.) Economic forces and the stock market. Journal of Business 59: 383-403.

Dodd, P., and Warner, J. B. (1983.) On corporate governance: A Study of proxy contests. Journal of Financial Economics 11: $401-438$.

Financial Accounting standards Board. (1984.) statement of Financial Accounting Concepts No. 5, Recognition and Measurement in Financial Statements of Business Enterprise. Norwalk, CT: FASB.

500 Contractors: Contractors Receiving the Largest Dollar Volume of Prime Contract Awards for RDT\&E. Washington DC: The Directorate.

Kalra, R., Henderson, G. V., Jr., and Raines, G. A. (1993.) Effects of the Chernobyl nuclear accident on utility share prices. Quarterly Journal of Business and Economics 32 : $52-77$.

Kaul, G., and seyhun, H. N. (1990.) Relative price variability, real shocks, and the stock market. Journal of Finance $45: 479-496$.

Lev, B., and Sunder, S. (1979.) Methodological issues in the use of financial ratios. Journal of Accounting and Economics 1: $187-210$. 
Meckstroth, D. J., and P. Buckley. (January 1991.) Implications of higher oil prices for U.S. industry. Business Economics $26: 34-39$.

Mitchell, M. L., and Maloney, M. T. (1989.) Crisis in the cockpit? The role of market forces in promoting air travel safety. Journal of Law and Economics 32: 329-355.

Norton, S. W. (1988.) Regulation, the OPEC oil supply shock, and wealth effects for electric utilities. Economic Inquiry $26: 223-238$.

Ohlson, J.A. (Spring 1980.) Financial ratios and the probalistic prediction of bankruptcy. Journal of Accounting Research $18: 109-131$

Ratajczak, D. (July-September 1990.) Persian Gulf crisis sends U.S. economy into recession. Business 40: 30-34.

Sachs, J. (1982.) The oil shocks and macroeconomic adjustment in the United States. European Economic Review 18: 243-248. Thomchick, E. (1993.) The 1991 Persian Gulf war: Short-term impacts on ocean and air transportation. Transportation Journal $33: 40-53$.

Uselton, G. C., and D. R. Fraser. (1988.) Risk and valuation in the petroleum industry: The consequences of the Arab oil Boycott. Managerial Finance 14: 16-24.

Zellner, A. (1962.) An efficient method of estimating seemingly unrelated regressions and tests for aggregation bias. American Statistical Association Journal 57: 348-368. 
Table 1

Chronological Listing of Events Around the Iraqi Invasion of Kuwait

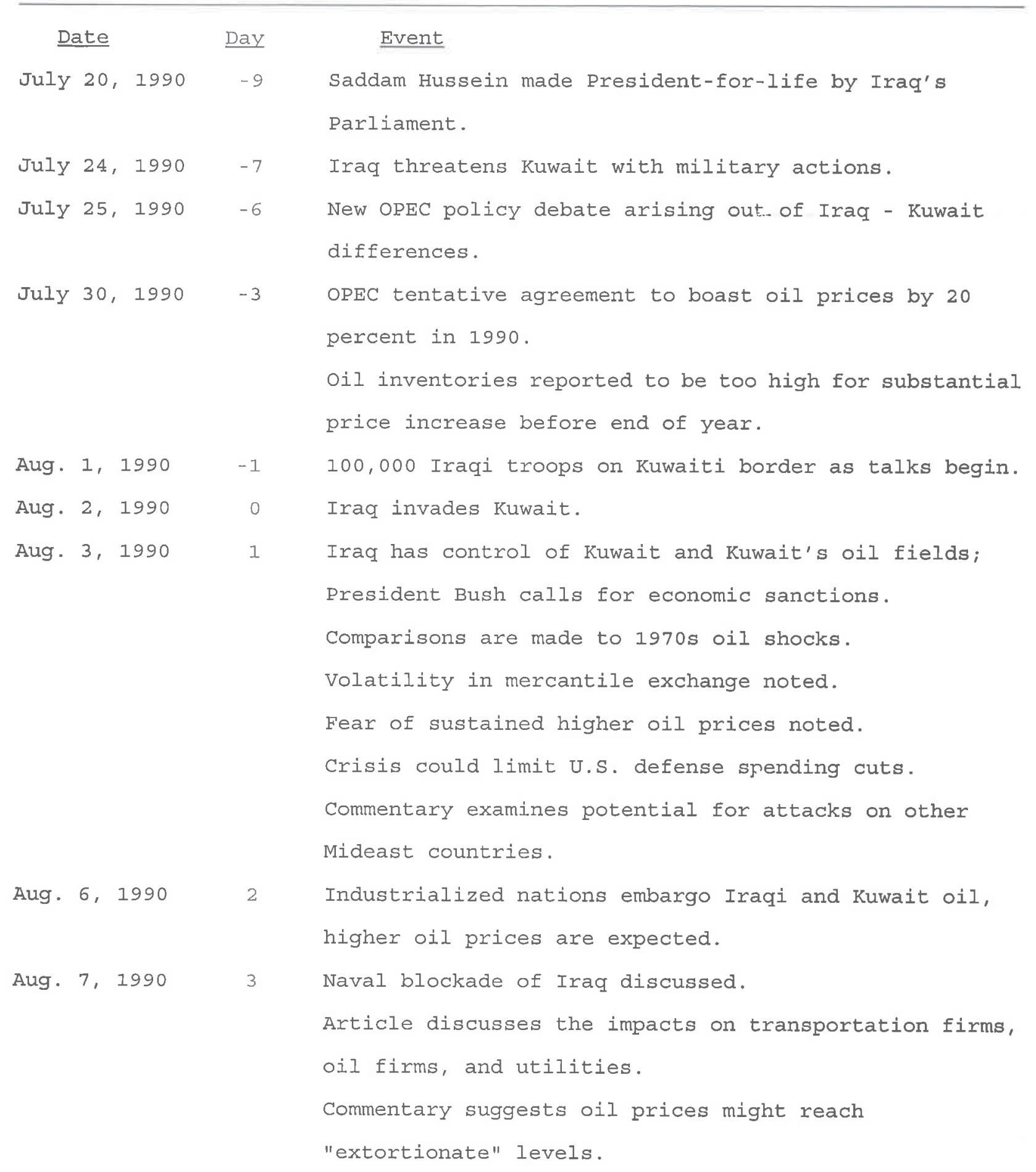


Table 1: continued

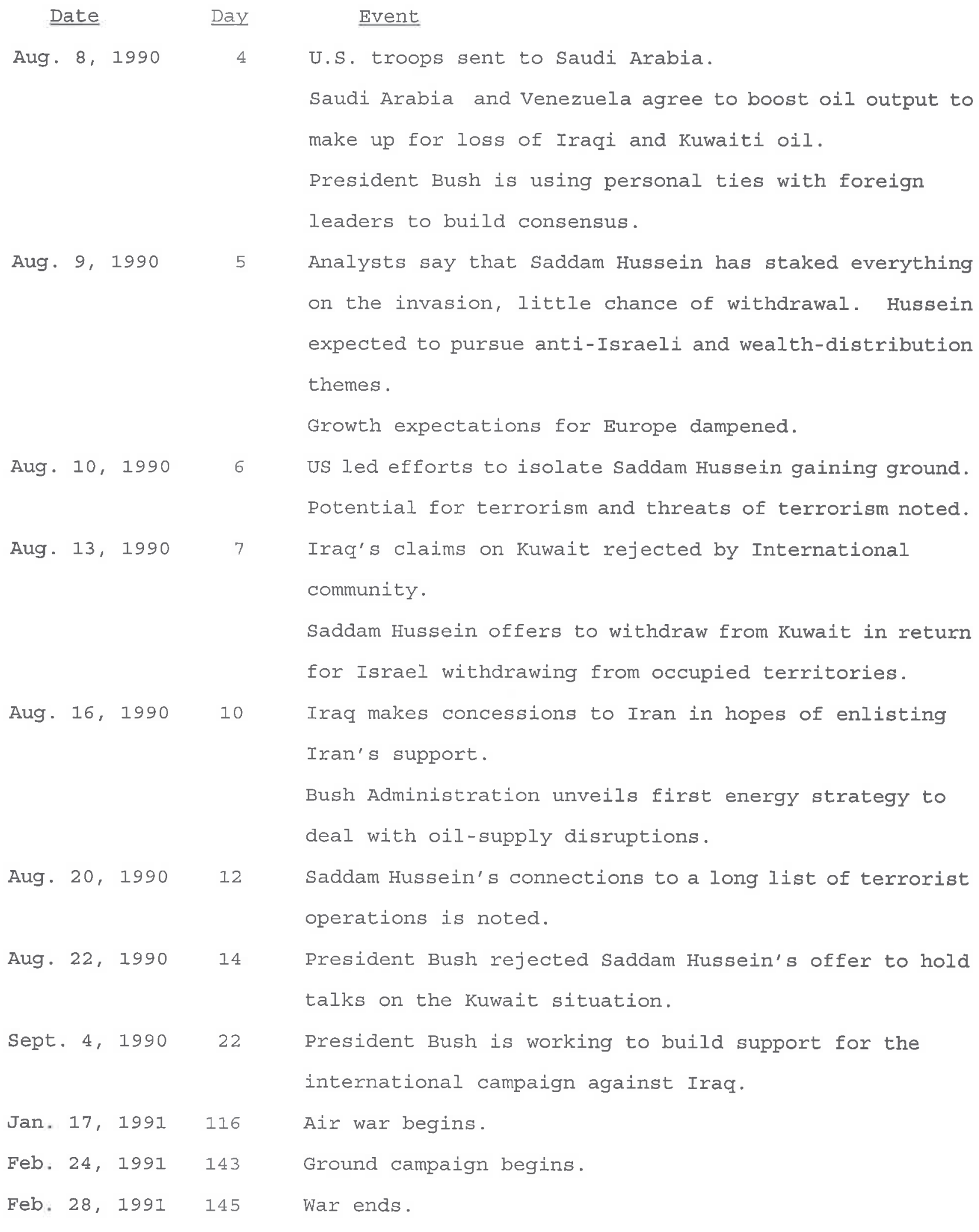


Table 2

Cumulative Abnormal Returns (CAR) for Various Intervals

\begin{tabular}{|c|c|c|c|}
\hline \multicolumn{2}{|c|}{ Period (days) * } & \multirow{2}{*}{$\begin{array}{l}\operatorname{CAR}(\%) \\
-0.76\end{array}$} & \multirow{2}{*}{$\begin{array}{c}\begin{array}{c}\text { Significance } \\
\text { Level* }\end{array} \\
0.184\end{array}$} \\
\hline-15 & to 15 & & \\
\hline-15 & to -2 & 1.18 & 0.558 \\
\hline & -1 & 0.60 & 0.893 \\
\hline & 0 & -0.29 & 0.179 \\
\hline & 1 & -0.37 & 0.132 \\
\hline & 2 & -0.05 & 0.317 \\
\hline & 3 & -0.71 & 0.036 \\
\hline & 4 & -0.17 & 0.226 \\
\hline & 5 & -0.50 & 0.072 \\
\hline & to 5 & -2.09 & 0.015 \\
\hline
\end{tabular}

*Day 0 is Aug. 2, 1990, the date of the invasion of Kuwait.

**Significance level $(p)$ is determined based on the frequency that randomly generated 'pseudo' CARs are less than or equal to CARs associated with the event (NLE) and the number of 'pseudo' CARs generated (NS) follciwing the formula: $p=(N L E+1) /(N S+1)$. 
Table 3

Changes in Risk for Individual Firms and a Portfolio of All Firms.

Panel A: Individual Firms

\begin{tabular}{|c|c|c|c|c|c|c|c|c|}
\hline & \multicolumn{4}{|c|}{ Systematic Risk } & \multicolumn{4}{|c|}{ Unsystematic Risk } \\
\hline & Sign & $N$ & Mean Ranks & Z-score & Sign & $\mathrm{N}$ & Mean Ranks & z-score \\
\hline All firms & - & 40 & 46.33 & & - & 17 & 33.76 & \\
\hline & + & 41 & 35.80 & -0.906 & + & 64 & 42.92 & $5.116 * \star \star$ \\
\hline
\end{tabular}

Panel B: Portfolio of Firms

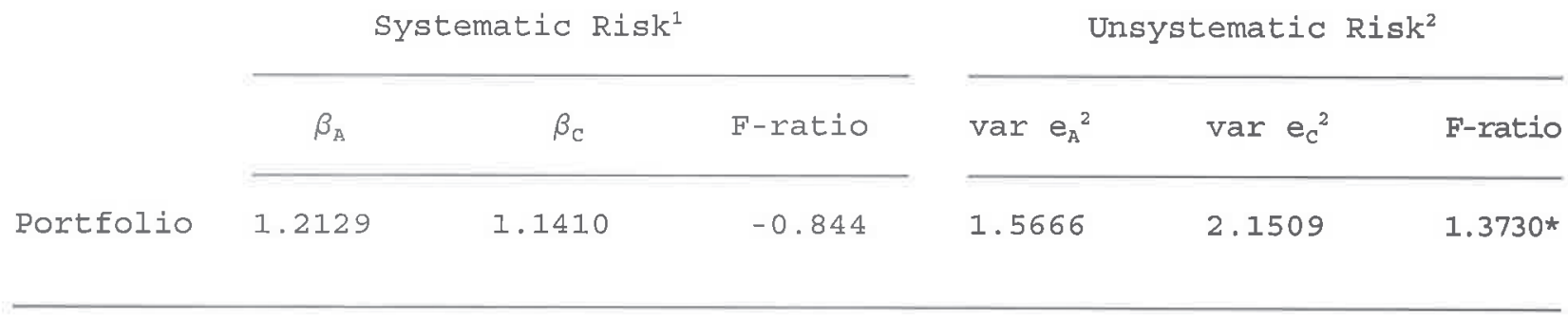

* Significant at the 0.10 level.

*** Significant at the 0.01 level.

1 Period $\mathrm{A}$ is the period prior to the invasion (days -215 to -16) and period C is the period after the war (days 161 to 360 ).

2 Variance in error terms, unsystematic risk, during the designated periods. 
Table 4. Cross-Sectional Regression Results

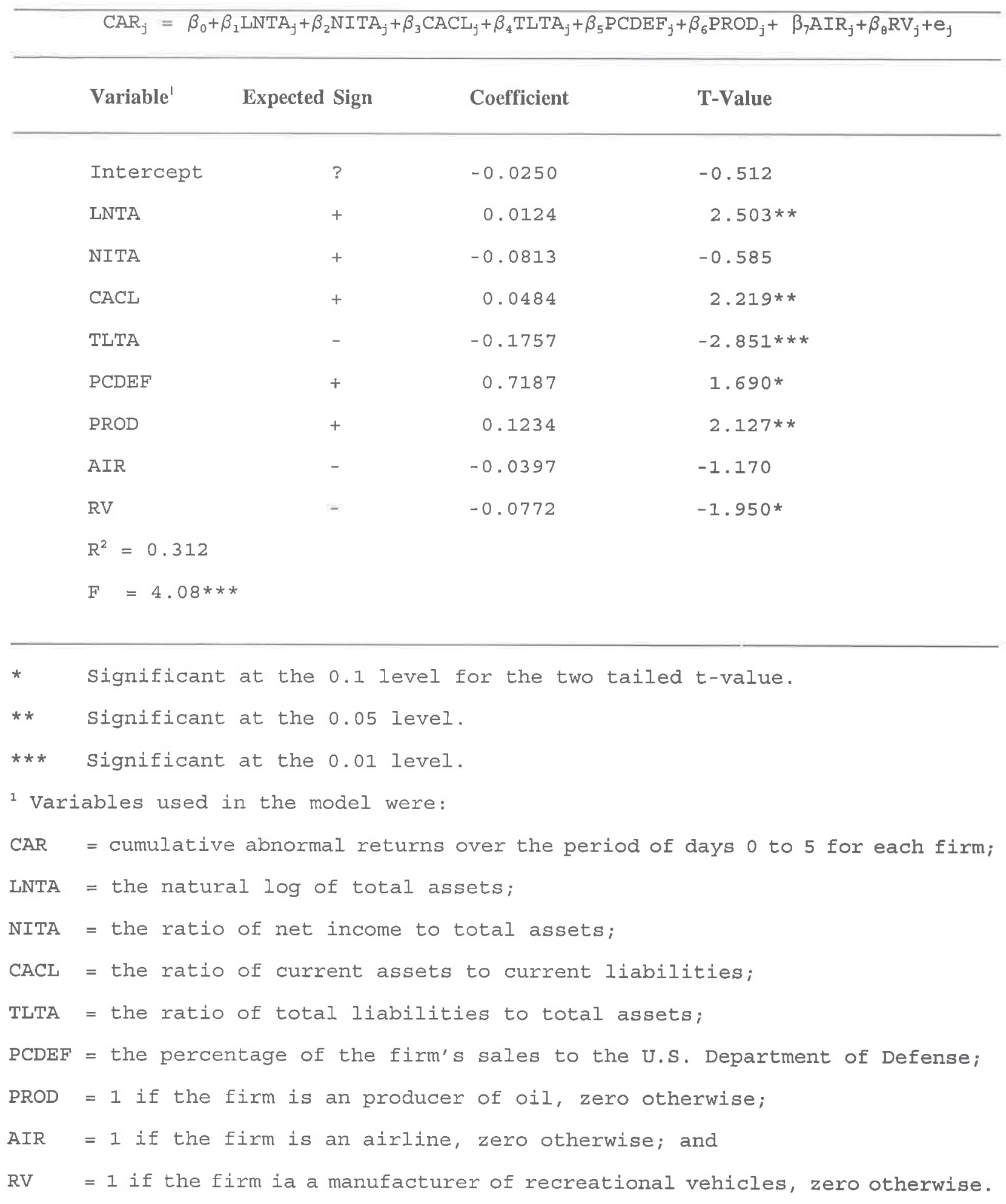

